\title{
ATIVISMO CEGO, ESPADA AMOLADA: ENSAIO SOBRE REVISÃO JUDICIAL DE ATOS POLÍTICOS
}

\author{
Blind Activism, Sharpened Sword: Essay on The Judicial Review of \\ Political Questions
}

Luis Lima Verde Sobrinho

Resumo: O presente artigo aborda a questão do ativismo judicial e a chamada teoria dos atos políticos, na perspectiva de discutir quais seriam os limites da revisão judicial sobre tais atos no Brasil, diferenciando-os dos tradicionais atos administrativos. Com metodologia exploratória e explicativa, o estudo aponta as possíveis limitações ao referido controle e propõe a adoção das ideias de democracia deliberativa e das teorias do diálogo institucional. O Poder Legislativo, enquanto fiscal político natural do governo deve ter maior participação nas lides que envolvem controle judicial de atos políticos, de modo a incrementar a legitimidade de atuação do Poder Judiciário. Juízes podem ser catalisadores do debate constitucional, num esforço para fazer da democracia um regime mais cooperativo e menos adversarial.

Palavras-chave: Separação de poderes. Atos políticos. Revisão judicial. Ativismo judicial. Diálogo institucional.

\begin{abstract}
This article analyzes the issue of judicial activism and the so-called theory of political questions to discuss the limits of judicial review concerning political questions in Brazil, differentiating them from traditional administrative questions. The study adopts both exploratory and explanatory approaches and indicates the possible limitations of judicial review, proposing the adoption of deliberative democracy ideas and theories of institutional dialogue. The legislative branch, as a natural political inspector of the government, must have greater participation in the processes that involve judicial review of political questions in order to increase the legitimacy of the judiciary's performance. Judges can be catalysts for constitutional debate in an effort to make democracy a more cooperative and less adversarial regime.
\end{abstract}

Keywords: Separation of powers. Political questions. Judicial review. Judicial activism. Institutional dialogue. 


\section{Introdução}

Ao lançar o olhar sobre as sociedades humanas, Aristóteles (384 a.C. - 322 a.C.) foi o primeiro a nelas distinguir três funções políticas essenciais: dizer a lei, executá-la e julgar os dissensos de acordo com ela (ARISTÓTELES, 1977). Todavia, a moderna sistematização dessa divisão veio a lume pela pena de Charles-Louis de Secondat, o Barão de Montesquieu (1689-1755), que, examinando a Constituição da Inglaterra, viu ali a semente moderna daquele princípio de organização política, e a partir daí esforçou-se por demonstrar como nessa realização estava a primeira garantia e a verdadeira salvaguarda da liberdade dos povos (MONTESQUIEU, 2008).

Não demoraria para que a experiência demonstrasse que uma separação absolutamente rígida de poderes traria problemas sempre que houvesse desarmonia entre as três instituições, situação que resultaria na seguinte constatação: para se livrar de um tirano, o povo então o teria substituído por outros três. Tal realidade propiciou o surgimento de teoria tendente a resolver o impasse: o sistema dos checks and balances, proposto pelos federalistas norte-americanos.

James Madison (1751-1836), a propósito desse ideário, publicou dois artigos em que trata da separação de poderes, que mais tarde seriam reunidos com artigos de Alexander Hamilton e John Jay, para formar a obra intitulada O Federalista, publicada em 1788. Ali, Madison propôs as mais conhecidas formas de equilíbrio e interferência de um poder sobre os outros dois, de modo a permitir que o sistema se mantenha estável pela horizontalidade do controle e pelas contenções recíprocas, resultando naquilo que se consagrou chamar de teoria dos freios e contrapesos (HAMILTON et al., 1984, p. 393-405).

Dois séculos depois, o Direito e a Ciência Política experimentaram novo problema atinente ao funcionamento das engrenagens da separação de poderes: a questão do ativismo judicial. Com o surgimento da noção de constitucionalismo democrático e de constituição dirigente a partir da segunda metade do século XX, direitos fundamentais individuais, coletivos, sociais e políticos passaram a ser incorporados nas constituições elaboradas após a Segunda Guerra, e a partir daí entrou em cena o protagonismo do Poder Judiciário, elevado à condição de guardião das novas ordens democráticas e dos direitos fundamentais. 
$\mathrm{Na}$ ordem do dia, portanto, está o problema do controle judicial das decisões políticas emanadas do Poder Legislativo e, sobretudo, do Poder Executivo. Estaria o princípio da separação de poderes em crise? Nesse contexto, o presente ensaio, tendo como recorte a situação do Brasil pós1988, objetiva analisar, especificamente, dois temas correlatos: o ativismo judicial e a discussão acerca da (in)sindicabilidade do mérito dos chamados "atos políticos". Afinal, o que caracterizaria o ativismo judicial e qual o limite de atuação do Poder Judiciário diante dos chamados "atos políticos" ou "atos de governo"?

Com metodologia exploratória e explicativa, o estudo, além desta introdução e da conclusão, apresenta-se em três seções, sendo a primeira sobre o ativismo judicial, a segunda sobre a teoria dos atos políticos e a última sobre a ideia central do trabalho: uma possível resposta à indagação do título - qual o limite de atuação do Poder Judiciário quando da revisão de decisões de natureza política dos demais Poderes?

\section{Considerações sobre o ativismo judicial}

Um dos legados das revoluções liberais burguesas dos séculos XVII e XVIII, sobretudo a Revolução Gloriosa da Inglaterra (1688), a Independência dos Estados Unidos da América (1776) e a Revolução Francesa (1789), foi o primado do juiz “boca da lei”. Até então, o Estado, bem como a criação e a interpretação do Direito, confundiam-se com a figura e a vontade dos próprios monarcas governantes, de modo que os parlamentos, onde existiam, não passavam de meros conselhos consultivos dos reis. Sepultados os regimes absolutistas após as ditas revoluções, surgiram as primeiras constituições escritas e teve início o movimento que se consagrou chamar de "constitucionalismo", a partir do qual a teoria de Charles-Louis de Secondat, o Barão de Montesquieu, teve grande adesão nas monarquias constitucionais e repúblicas então (re)fundadas (MONTESQUIEU, 2008).

Referida teoria, ao defender a divisão do poder estatal em três funções essenciais (Legislativo, Executivo e Judiciário), realçava a importância do Legislativo, porquanto seria o poder dotado de maior legitimidade representativa e racionalidade plural. Atribuiu-se à lei emanada do Parlamento uma supremacia incontrastável. Caberia ao Poder Executivo, na condução do governo, rigorosamente executar o direito legislado, e ao Judiciário, na solução dos conflitos sociais, friamente aplicar aquele direito posto. Vem 
daí o primado do juiz "boca da lei”, ou seja, o papel da magistratura deveria se restringir a declarar qual o direito positivo seria aplicável à solução do caso concreto.

A era do constitucionalismo teria durado até a metade do século XX, de modo que após a Segunda Guerra Mundial, inaugurou-se o momento a partir do qual o papel do Estado foi sendo gradativamente redesenhado. A guerra deixou um cenário de destruição social, econômica e estrutural. Some-se a isso a herança dos inúmeros regimes jurídicos autoritários. As profundas cicatrizes deixadas pelo conflito resultaram na formulação de novas propostas jusfilosóficas dispostas a reconhecer o fracasso do Estado de Direito - o que se verificara durante os regimes totalitários -, apontando para a necessidade de se afirmar a superação da lógica formalista do Direito (TRINDADE, 2012, p. 112).

A partir de tais mudanças, surge a noção de constitucionalismo democrático e de constituição dirigente (CANOTILHO, 2001), e o fenômeno jurídico passa a ser percebido sob um viés de materialidade, de substancialidade, em vez de formalidade. Tudo isso por meio da inclusão de dois postulados centrais: o reconhecimento da força normativa da Constituição (HESSE, 1991) e da incorporação de novas garantias, novos direitos aos cidadãos, com seus respectivos meios assecuratórios (STRECK, 2004). Direitos fundamentais individuais, coletivos, sociais e políticos passaram a ser incorporados nas constituições elaboradas após a guerra, e a partir daí entra em cena o protagonismo de outro poder: o Judiciário, elevado à condição de fiador das novas ordens democráticas e dos direitos fundamentais.

Para tirar tais direitos do papel, Cortes constitucionais, nesse novo cenário global, assumem a dianteira, em maior ou menor proporção, a depender da realidade própria de cada Estado, em frontal reação à postura do juiz "boca da lei", criada pelo ideário liberal burguês e fruto do Estado Legislativo de Direito. Surge, portanto, a ideia de Estado Constitucional de Direito e o paradigma do neoconstitucionalismo, como suposta superação do constitucionalismo. "O resultado disso será um constitucionalismo voltado à superação da debilidade estrutural do âmbito jurídico presente no Estado Legislativo de Direito", aponta Oliveira Neto (2011, p. 550).

O neoconstitucionalismo teria como características essenciais: i) a relação conceitual entre Direito e Moral, restabelecida pela incorporação, nas Constituições, de princípios de justiça de caráter ético-político (constitucionalismo ético); ii) grande parte das normas constitucionais configuram-se 
como princípios - e, portanto, são estruturalmente diferentes das regras os quais implicam valores e se encontram em constante conflito, sobretudo nos chamados casos difíceis; iii) o papel central atribuído à argumentação jurídica, mais especificamente à ponderação, confiada à atividade desempenhada pelos juízes (TRINDADE, 2012, p. 101).

A partir desse contexto, o ativismo judicial surge como fruto do paradigma neoconstitucionalista, em reação ao formalismo jurídico e àquela máxima do juiz como mero aplicador da lei. Além disso, o ativismo tem por indissociáveis o Direito e a Política. Segundo Thamy Pogrebinschi (2000, p. 2), considera-se ativista o juiz que "(a) use o seu poder de forma a rever e contestar decisões dos demais poderes do estado; (b) promova, através de suas decisões, políticas públicas; (c) não considere os princípios da coerência do direito e da segurança jurídica como limites à sua atividade”.

Especificamente, o ativismo judicial nasce no sistema jurídico norte-americano, em que os precedentes constituem a principal fonte do Direito e, portanto, a atividade jurisdicional implica a própria criação desse (TRINDADE, 2012, p. 110). Tal fenômeno teria atingido seu ápice com a conhecida Corte Warren - presidida por Earl Warren, durante as décadas de 1950 e 1960 -, quando decisões históricas foram proferidas, o que provocou verdadeira revolução na hermenêutica constitucional, e influenciou, decerto, a atividade de muitas outras cortes mundo afora, a exemplo do famoso caso Brown vs. Board Education, de 1954. Na década de 1970, a Corte Burguer manteve a tradição das decisões rotuladas de ativistas (WOLFE, 1994).

A primeira menção ao termo ocorreu em 1947, nos Estados Unidos, feita por Arthur Schlesinger, em artigo intitulado The Supreme Court: 1947, publicado na revista Fortune, no qual o autor classificou os juízes da Suprema Corte americana como ativistas (activists) ou passivistas - os últimos caracterizados pela autocontenção judicial (self-restrain) (DIAS; SÁ, 2020, p. 168).

Tendo como premissa maior a divisão das normas jurídicas em duas espécies, princípios e regras, o primeiro elemento a caracterizar o ativismo judicial seria a presença de decisões fundamentadas substancialmente em princípios, afastando ou negando a aplicabilidade de regras específicas para a fattispecie (TEIXEIRA, 2012, p. 46). A partir desse traço essencial que o caracteriza, o ativismo judicial pode se manifestar de forma positiva ou negativa, segundo a classificação de Anderson Vichinkeski Teixeira (op. cit.). 
Ativismo judicial positivo seria "aquele que se enquadra no padrão de racionalidade jurídica vigente no ordenamento em questão e busca, em última instância, assegurar direitos fundamentais ou garantir a supremacia da Constituição" (TEIXEIRA, 2012, p. 46). Ainda segundo Teixeira (op. cit., p. 52), estando-se diante de algum dos seguintes elementos, pode-se cogitar de ativismo positivo: (1) decisão fundamentada substancialmente em princípios jurídicos, sobretudo os constitucionais; (2) decisão que busque precipuamente assegurar direitos fundamentais; (3) decisão orientada à garantia da supremacia da Constituição; e (4) decisão sustentada por técnicas hermenêuticas que não extrapolem a mens legis e não derroguem a mens legislatoris do ato normativo em questão.

Mesmo para os teoristas mais críticos ao ativismo judicial, parece não haver dúvida de que os direitos fundamentais devem preponderar, como regra, frente às demais normas do ordenamento jurídico, inclusive aqueloutras que possuam status constitucional. Dito isso, o ativismo judicial, quando presidido pelas diretivas acima sugeridas, em tese não mereceria reproche hermenêutico. Aliás, há quem defenda, a exemplo de Teixeira (op. cit., p. 52), tratar-se de "uma patologia constitucional cada vez mais necessária - desde que seja na sua vertente positiva -, para a proteção do indivíduo contra as omissões ou excessos do Estado".

Já o ativismo judicial negativo se fará presente sempre que prepondere "um padrão de racionalidade eminentemente político" (TEIXEIRA, 2012, p. 46). Dentre as diversas concepções encontráveis sobre a manifestação deletéria do ativismo judicial, uma das mais amplas talvez seja a de Willian Marshall (2002), que enumera sete comportamentos nocivos: 1) quando os tribunais discordam de decisões tomadas por órgãos democraticamente eleitos (ativismo contramajoritário); 2) quando os tribunais desconsideram as concepções mais estritas do texto legal ou, então, a intenção original dos autores da Constituição (ativismo não originalista); 3) quando os tribunais rejeitam a aplicação de precedentes estabelecidos (ativismo de precedentes); 4) quando os tribunais não obedecem os limites formais estabelecidos de sua atuação, e ultrapassam as competências a eles conferidas (ativismo jurisdicional); 5) quando os tribunais criam, materialmente, novos direitos e teorias por meio da doutrina constitucional (ativismo criativo); 6) quando os tribunais impõem obrigações positivas aos outros poderes ou controlam o cumprimento das medidas impostas (ativismo remediador); 7) quando os 
tribunais decidem com a finalidade de atingir objetivos nitidamente partidários ou de determinado segmento social (ativismo partisan).

$\mathrm{Na}$ Europa, o ativismo tomou impulso a partir do movimento nascido na Alemanha chamado jurisprudência de valores. Após o término da guerra, com a promulgação da Constituição de Bonn em 1949, o Tribunal Constitucional alemão recebeu a missão estratégica de romper com o modelo jurídico vigente, de base nazista, e, paralelamente, legitimar as recentes decisões tomadas com base no novo regime, instaurado pelos aliados. Nesse contexto, buscando superar os impasses da velha legislação e romper com o positivismo legalista, a jurisprudência de valores se viu obrigada a recorrer a alternativas metodológicas - muitas vezes invocaram-se direitos supralegais - capazes de evitar o formalismo que caracterizava a tradição jurídica alemã (TRINDADE, 2012, p. 112 - 113).

No Brasil, essas duas experiências - a norte-americana e a alemã - terminaram produzindo efeitos diretos a partir da promulgação da CF, o que resultou na geração de um ativismo sui generis, que vem sendo praticado não apenas pelo STF, mas também pelas demais instâncias do Poder Judiciário, inclusive pelos juízes singulares. A ausência, no Direito brasileiro, de mecanismos formais de unificação vinculante de jurisprudência é fator de grande insegurança jurídica num cenário de crescente ativismo judicial.

O resultado disso, aponta Trindade (op. cit., p. 117), foi a institucionalização de um "verdadeiro ativismo judicial às avessas, em que se confere discricionariedade aos juízes para, nos casos concretos, buscarem em suas consciências uma solução que atenda aos fins de justiça social”, de modo a se ter "14 mil magistrados em atividade, cuja grande maioria ainda entende que a interpretação é um ato de vontade e que, portanto, está à disposição do juiz" (TRINDADE, 2012, p. 116). Em síntese, "o ativismo começa quando, entre várias soluções possíveis, a escolha do juiz é dependente do desejo de acelerar a mudança social ou, pelo contrário, de a travar" (GARAPON, 1996, p. 54).

\section{A teoria dos atos políticos}

A teoria dos atos políticos possui matriz tanto no Direito estadunidense (political question doctrine), quanto no francês (théorie des actes de gouvernment). As controvérsias do tema já se iniciam na denominação. Encontram-se, com maior frequência, as expressões "ato de governo" e "ato 
político". No léxico norte-americano, todavia, utiliza-se a locução "political questions", enquanto que no inglês, "acts of state" (MEDAUAR, 1993; QUEIROZ, 1990; CRETELLA JÚNIOR, 1987).

A essência do pensamento assenta na ideia de que certos atos estatais não estariam sujeitos à revisão judicial. Vale ter presente que o século XVIII propiciou duas das mais importantes revoluções liberais burguesas do mundo: a Independência dos Estados Unidos da América (1776) e a Revolução Francesa (1789). A adoção de um rígido modelo de separação de poderes, em ordem a conter a tirania estatal, foi a bandeira comum nas duas Revoluções, surgindo a partir daí a ideia de que o Poder Judiciário não teria legitimidade para desconstituir atos de governo.

Cumpre rememorar que, no Brasil, por exemplo, as Constituições de 1934 e de 1937 continham cláusulas expressas que afastavam da revisão judicial as questões "exclusivamente políticas”. Além do mais, mesmo sob a égide das Constituições anteriores - a imperial de 1824 e a republicana de 1891 -, apesar de inexistirem regras explícitas nesse sentido, o próprio Poder Judiciário adotava jurisprudência de autocontenção, recusando-se a avançar sobre decisões políticas dos demais poderes.

Contudo, a era do constitucionalismo, inaugurada após a Segunda Guerra Mundial, tratou de elevar o Poder Judiciário ao patamar de fiador da ordem democrática e dos direitos fundamentais recém-inseridos nos textos constitucionais, enfraquecendo, ou mesmo neutralizando, a velha máxima de que haveria atos estatais postos acima do alcance da revisão judicial. No Brasil, desde a Constituição de 1946, vigora o princípio da inafastabilidade da jurisdição, o qual, na vigente Constituição de 1988, situa-se no art. 5ำ, inciso XXXV, a saber: "a lei não excluirá da apreciação do Poder Judiciário lesão ou ameaça a direito". Sendo assim, ao menos no Brasil, há muito já não se cogitam de atos estatais insindicáveis, ainda que possuam natureza eminentemente política. Quando muito, a possibilidade de revisão judicial do ato pode ser limitada, porém, jamais afastada. Restaria saber quais seriam os tais limites.

Numa democracia, não há falar em atos infensos ao controle judicial. A responsabilidade institucional associa-se à chamada horizontal accountability, ou seja, "a capacidade de certas instituições [...] controlarem a actividade das outras [...] e dos respectivos titulares", afirmam Correia e Pinto (2010, p. 37). Conforme as lições de Pedro Lomba (2008, p. 76-77), "quanto mais representativos, mais responsáveis foram e são obrigados a 
ser os titulares do poder público", de modo que a responsabilidade política ou a accountability significa a "obrigação de prestar contas". Sendo assim, qualquer bandeira que se erga a defender a impossibilidade de revisão judicial de atos de governo estará a serviço do autoritarismo. A discussão deve circunscrever-se, apenas, ao quanto de revisão judicial é possível; nunca ao se é possível.

Vencido, pois, o ideário da insindicabilidade dos atos políticos, a teoria em exame mantém relevância científica, na medida em que propõe a existência, ao lado das funções legislativa, administrativa e jurisdicional, de uma quarta, denominada "função política" ou "função de governo", cujo desempenho caberia, em maior medida, ao Poder Executivo, e que possuiria natureza jurídica própria. Aqueles que defendem a existência autônoma dessa quarta dimensão de poder sustentam que as funções estatais não podem mais ser concebidas pelo modelo clássico do século XVIII, de sorte que nem só de atos administrativos viveria o Poder Executivo, porquanto, ao lado destes, seriam produzidos, também, os chamados "atos políticos". Governar e administrar seriam, pois, coisas distintas, à luz de tal teoria (QUEIROZ, 1990). A própria CF evidencia isso ao tratar, separadamente, da Administração Pública no Capítulo VII do Título III (Da organização do Estado), e da organização dos Poderes no Título IV.

Haveria, portanto, um dualismo orgânico-institucional entre Administração Pública, cujo titular é a burocracia, e governo e parlamento, cujo titular é a classe política. A burocracia seria caracterizada, na tradição de Max Weber (1982), como uma organização formal que se pauta por regras fixas na sua atuação, nomeadamente, pelos princípios da competência, da hierarquia, da carreira escalonada etc. A burocracia seria caracterizada por subordinar-se a decisões políticas (WEBER, 1982). A tomada de decisões para serem executadas pela burocracia cabe basicamente à classe política. Em consonância com tal função, a estrutura desta última é, no essencial, distribuída não hierarquicamente, mas horizontalmente; as competências não estão tão claramente delimitadas (cláusulas abertas); e ao princípio da carreira escalonada contrapõe-se a dependência de eleições periódicas.

Antes que se possa imaginar que ato político seria apenas outra face do ato administrativo discricionário, cumpre observar que a literatura que se debruça sobre o tema estabelece nítida distinção entre tais coisas (FERNÁNDEZ-VALMAYOR, 1967). Os atos políticos retirariam seu fundamento de legitimidade diretamente das constituições, sem interpositio legis. 
Já o ato administrativo, seja o vinculado ou o discricionário, retiraria semelhante fundamento de normas infraconstitucionais. Outra elementar diferença diria respeito aos sujeitos que praticam tais atos - quaisquer agentes públicos seriam competentes para praticar atos administrativos, enquanto que atos políticos somente poderiam ser praticados por agentes políticos (os ocupantes de cargos estruturais na organização política do País, cujas funções são típicas de Estado). Demais disso, numa escala a partir do ato administrativo vinculado, passando pelo ato administrativo discricionário e findando no ato político, o espaço para revisão judicial seria decrescente. É dizer: a sindicabilidade judicial do ato administrativo vinculado seria máxima e a do ato político seria mínima.

Ato político, pois, é "ato jurídico voluntário", que corresponde, concretamente, a uma manifestação de vontade de um órgão ou agente do poder político do Estado, concernente à prossecução dos seus fins e ao exercício de suas funções, manifestação de vontade essa que visa à produção de efeitos jurídicos, afirma Marcelo Rebelo de Sousa (1988, p. 106). Os atos políticos, portanto, refletem as opções fundamentais de uma sociedade, manifestadas por meio do regular processo democrático, cuja finalidade é definir os rumos do Estado. Essencialmente, tais atos vinculam-se apenas aos fins primários do Estado, cuja generalidade e amplitude condizem com a necessária margem de discricionariedade existente na formação da vontade política (SOUSA, 1988).

Os atos políticos são praticados pelos órgãos de cúpula dos poderes constituídos que exercem a função política (basicamente, parlamento e governo) e estão descritos diretamente na Constituição, sem que o rol, todavia, seja taxativo (PIÇARRA, 1989). Para os fins a que se destina este trabalho, interessa mencionar aqueles cuja competência é constitucionalmente atribuída ao Presidente da República. Nada obstante, releva destacar que o Congresso Nacional (art. 49), a Câmara dos Deputados (art. 51) e o Senado Federal (art. 52) também possuem competência para editar atos políticos, como, por exemplo, autorizar o Presidente da República a declarar guerra, a celebrar a paz, a permitir que forças estrangeiras transitem pelo território nacional ou nele permaneçam temporariamente (Congresso Nacional); autorizar, por dois terços de seus membros, a instauração de processo contra o Presidente e o Vice-Presidente da República e os Ministros de Estado (Câmara dos Deputados); processar e julgar o Presidente e o Vice-Presidente da República nos crimes de responsabilidade, bem como os Ministros de 
Estado e os Comandantes da Marinha, do Exército e da Aeronáutica nos crimes da mesma natureza conexos com aqueles (Senado Federal).

Assim sendo, os atos políticos ou de governo exercitáveis pelo chefe do Poder Executivo Federal estariam basicamente descritos no art. 84 da CF, segundo o qual compete privativamente ao Presidente da República, v.g., nomear e exonerar os Ministros de Estado (inciso I); sancionar, promulgar e fazer publicar as leis, bem como expedir decretos e regulamentos para sua fiel execução (inciso IV); vetar projetos de lei, total ou parcialmente (inciso V); manter relações com Estados estrangeiros e acreditar seus representantes diplomáticos (inciso VII); celebrar tratados, convenções e atos internacionais, sujeitos a referendo do Congresso Nacional (inciso VIII); decretar o estado de defesa e o estado de sítio (inciso IX); conceder indulto e comutar penas, com audiência, se necessário, dos órgãos instituídos em lei (inciso XII); nomear, após aprovação pelo Senado Federal, os Ministros do Supremo Tribunal Federal e dos Tribunais Superiores, os Governadores de Territórios, o Procurador-Geral da República, o presidente e os diretores do banco central e outros servidores, se determinado em lei (inciso XIV); declarar guerra, no caso de agressão estrangeira, autorizado pelo Congresso Nacional ou referendado por ele, quando ocorrida no intervalo das sessões legislativas, e, nas mesmas condições, decretar, total ou parcialmente, a mobilização nacional (inciso XIX); celebrar a paz, autorizado ou com o referendo do Congresso Nacional (inciso XX); conferir condecorações e distinções honoríficas (inciso XXI) etc.

Conforme se vê, a CF consagrou expressamente espécies de atos que, não compreendidos em nenhuma das demais funções de Estado, podem ser qualificados como atos políticos. Marçal Justen Filho (2014, p. 125), por sua vez, esclarece que a função de governo:

[...] indica um conjunto de competências não relacionadas propriamente à satisfação de necessidades essenciais. São aquelas atinentes à existência do Estado e à formulação de escolhas políticas primárias. [...] A função de governo também envolve a realização dos direitos fundamentais, mas não consiste numa medida diretamente referida a isso. Quando um presidente firma um tratado internacional, desempenha uma função política. Mas há função administrativa quando firma um contrato administrativo. A distinção não é simples, especialmente porque existem elementos políticos no desempenho de função administrativa, tal como há uma carga administrativa na função política. 
Ainda que perceptível, em algumas situações, a distinção entre atividades de governo (decisões políticas fundamentais sobre políticas públicas, sobre relações exteriores etc.) e atividades administrativas (prestação de serviços públicos, licitações etc.), fato é que não existe fronteira rígida entre essas duas funções. A distinção, algumas vezes, é utilizada com o propósito de blindar atos políticos do controle judicial, o que, na vigente ordem constitucional brasileira, deve ser refutado, pois ato jurídico nenhum - tenha natureza política ou administrativa - escapa, em princípio, da possibilidade de revisão judicial, por força do art. 5ํ, XXXV, da CF, o que resta demonstrado, v.g., pelo fenômeno da judicialização da política.

Essa dificuldade de delimitação dos espaços da função política e da função administrativa resulta, pois, na constatação de que "na prática da atuação do Executivo ocorre, em geral, um emaranhado de governo e administração, o que, segundo alguns, permite evitar um governo puramente político e uma administração puramente burocrática”, assinala Odete Medauar (2006, p. 47). De fato, é evidente a existência de uma interface entre ambas as funções. Contudo, sendo as funções administrativa e política distintas, tecnicamente deve existir uma linha divisória entre elas, ainda que tênue, sob pena de se aplicar a certos atos o regime jurídico destinado a outros.

Por fim, cumpre mencionar que a teoria do ato político encontra resistências doutrinárias, como a oferecida por Nuno Piçarra (1989, p. 240), para quem:

A ideia de uma profunda fronteira entre o binómio Governo-Parlamento e a Administração é, contudo, insustentável: no Estado constitucional, a Administração é necessariamente dirigida pelas forças políticas. Por outro lado, a própria burocracia traz em si elementos inegavelmente políticos, o que é especialmente evidente no caso das chefias burocráticas ministeriais. A separação destas da classe dos dirigentes políticos não é material, mas formal-institucional. Porque a condução da burocracia está (deve estar), em última instância, nas mãos dos dirigentes políticos sediados no governo e no parlamento, ela não pode apresentar-se perante estes como absolutamente autónoma e independente. 
Outra espécie de crítica recebida diz respeito à suposta pretensão, dessa teoria, de afastar o controle judicial sobre atos que seriam artificialmente rotulados como "políticos". Nesse sentido, Fernández-Valmayor (1967, p. 128):

[...] podemos afirmar sin ninguna duda la inexistencia de una categoría de actos llamados 'políticos' o de gobierno. El predicar la politicidad de un acto con el fin de excluirlo de la revisión judicial sólo puede obedecer a razones de oportunidad política injustificables desde el punto de vista jurídico, y constituye un arbitrario atentado contra los derechos y libertades de los ciudadanos, que en todo Estado de Derecho deben estar perfectamente garantizados.

A questão, contudo, não é colocar Governo e Administração Pública como instituições independentes e autônomas, defrontadas em pé de igualdade. A Administração, em última instância, é governada por agentes políticos, e à politica de Estado se submete. O que releva distinguir é a natureza jurídica dos atos praticados por um e por outro sistema. A Administração Pública produz atos administrativos; o governo produz atos políticos. Demais disso, a autonomia dos atos políticos não lhes retira o DNA de atos jurídicos e, por isso mesmo, permanecem sujeitos ao controle de verificação de regularidade em face da ordem jurídica, e isso não está em discussão, sobretudo no Brasil, onde existe previsão constitucional expressa sobre a inafastabilidade da jurisdição. Em que pese a crítica dos refratários à teoria dos atos políticos, tal diferenciação parece bastante coerente e útil para a compreensão do problema da judicialização da política e do ativismo judicial. A teoria em debate fornece ricos elementos de reflexão acerca dos possíveis limites para uma revisão judicial legítima, o que será abordado na próxima seção.

\section{Limites ao controle judicial de atos políticos}

"Justiça Federal suspende posse de Cristiane Brasil no Ministério do Trabalho" (G1, 08/01/2018); "Ministra Cármen Lúcia suspende dispositivos de decreto que amplia regras para concessão de indulto" (STF, 28/12/2017); "Nomeação de Moreira Franco como ministro é suspensa pela segunda vez" (Conjur, 09/02/2017); "Ministro Teori Zavascki afasta deputado Eduardo Cunha de funções na Câmara" (Conjur, 05/05/2016); 
"Marco Aurélio manda Cunha dar seguimento a impeachment de Temer" (Conjur, 05/04/2016); “Gilmar Mendes suspende nomeação de Lula como ministro da Casa Civil”" (G1, 18/03/2016). O que essas manchetes de jornal têm em comum? Todas dizem respeito a controle judicial exercido sobre atos políticos. O que elas têm de incomum? Em todas, o Judiciário proferiu a palavra final sobre decisões políticas de outros Poderes. Já se adianta que não é pretensão deste ensaio analisar as razões meritórias de cada uma dessas decisões judiciais. O objetivo ora desejado é tão somente o de trazer uma possível reflexão sobre os limites constitucionais da sindicabilidade de atos políticos.

Conforme já foi visto, “a lei não excluirá da apreciação do Poder Judiciário lesão ou ameaça a direito", segundo o art. 5, XXXV, da CF. Assim, todo e qualquer ato, comissivo ou omissivo, inclusive político, que venha a ameaçar ou lesar direitos, estará sujeito à revisão judicial. As duas Constituições anteriores - 1946 e 1967/69 -, que continham semelhante garantia, eram mais restritivas, porquanto limitavam o controle judicial apenas aos casos de efetiva lesão a direitos individuais. Em ambas, a redação era a mesma: "A lei não poderá excluir da apreciação do Poder Judiciário qualquer lesão de direito individual”. A CF de 1988 tratou de ampliar a garantia, ao incluir, além da lesão efetiva, a ameaça de lesão, e retirando o adjetivo individuais para proteger qualquer direito. Dito isso, evidencia-se que a política encontra-se "submetida a um complexo de sistemas de imposições e limitações constitucionais. Da sua conformidade ou desconformidade com a parametricidade da norma constitucional depende em larga medida a questão da sua constitucionalidade" (QUEIROZ, 1990, p. 147).

Seja como for, para efeito de sindicabilidade, é indiferente perscrutar a natureza do ato, porquanto qualquer que seja ela, este será, antes de tudo, ato jurídico. Portanto, o fato de ser ato político não o isenta do controle jurisdicional de validade constitucional. Diga-se mais: tampouco o imuniza de outras formas de controle, a exemplo do controle político exercitável pelo Poder Legislativo ou do controle administrativo a cargo dos tribunais de contas e das controladorias e auditorias internas.

Nesse passo, visto que o ato político retira seu fundamento de legitimidade diretamente da Constituição, os requisitos formais e materiais que lhe conferem validade devem estar todos na própria Constituição. É dizer: não cabe ao Poder Judiciário invalidar ato político com base unicamente em parâmetros infraconstitucionais. Essa seria a primeira limitação 
posta, a qual já o diferencia do ato administrativo. Será, pois, a partir da observância satisfatória desses pontos, tais como o atendimento dos requisitos formais e materiais estabelecidos pela Constituição, que se poderá concluir pela validade, regularidade ou existência dos atos políticos e, de modo concludente, por sua acomodação harmônica ao Direito (CALDEIRA, 2014).

Acerca dos requisitos do ato jurídico-constitucional, Marco Caldeira (2014, p. 107) aponta que estes devem: a) ser provenientes de órgãos competentes; b) ser praticados pelo agente político constitucionalmente legitimado, sem contaminação de vício de vontade; c) ser direcionados ao fim previsto na Constituição; d) atender à forma prevista pela Constituição; e) ser o resultado final de procedimento em cujo âmbito observaram-se todas as formalidades estipuladas.

Conquanto seja difícil verificar, algumas vezes, violações diretas a direitos, liberdades e garantias, em decorrência da prática de atos políticos, a observância desses parâmetros surge antes como obrigação constitucional, reveladora de um dever negativo (não fazer), um dever genérico de abstenção, de não violação. Mas isso não basta. A vinculação às normas que estabelecem direitos, liberdades e garantias há de ser observada também na vertente positiva, nos casos em que a preservação desses direitos, liberdades e garantias demande um agir estatal (OTERO, 2007).

Nesse passo, importa dizer que os limites à revisão judicial são de tal ordem que à jurisdição (especialmente a constitucional) competirá dizer o direito sem que, ao fazê-lo, tome as rédeas de outro centro de poder. Esse tem sido o argumento utilizado para limitar, no que pertine ao conteúdo do ato, a atuação da jurisdição constitucional, pois as decisões políticas que integram os atos políticos não poderiam ser apreciadas quanto à conveniência ou à oportunidade, sob pena de manifestação deletéria de ativismo judicial.

Acrescente-se que tanto a competência para produção do ato político, como para a revisão judicial, emanam da própria Constituição, sem hierarquização, de modo que não cabe à jurisdição inovar as razões políticas justificadoras do ato revisado, cingindo sua apreciação à análise do comando constitucional prévio, ao qual o ato político deve (ou deveria) estar vinculado. É dizer: o papel do Judiciário limita-se a desfazer o ato, para proteger o direito lesado; jamais refazê-lo. Logo, o controle jurisdicional da constitucionalidade dos atos políticos seria limitado na e pela Constituição. 
Especificamente quanto aos vícios estritamente procedimentais do ato político - competência e forma -, a cognição jurisdicional é ampla, não se distinguindo, no ponto, do que ocorre no controle dos atos administrativos. A título de exemplo, se um agente público pratica ato administrativo para o qual não detinha competência legal ou se um agente político pratica ato político para o qual não estava investido de competência constitucional, o Poder Judiciário estará autorizado a invalidar ambos, com a mesma margem de liberdade. A diferença surgiria em relação ao limite de revisão do conteúdo do ato político.

De há muito, percebe-se o esforço doutrinário e jurisprudencial no sentido de identificar elementos vinculados nos atos administrativos discricionários, com a possibilidade de controle judicial desses aspectos: incompetência do agente, vício de forma e desvio de finalidade. Eduardo García de Enterría (1995), referindo-se a uma suposta luta contra a imunidade da Administração, elenca as seguintes conquistas rumo à ampliação da sindicabilidade dos atos administrativos discricionários: a) reconhecimento de que todos os atos discricionários possuem elementos regrados - competência e forma - suscetíveis de sindicância judicial; b) inclusão da finalidade como um dos aspectos sindicáveis dos atos administrativos; c) admissão do controle da veracidade ou não dos fatos determinantes dos atos da Administração; e d) a distinção entre discricionariedade e conceito jurídico indeterminado, permitindo-se maior controle acerca destes últimos.

Todavia, em relação à revisão judicial de atos políticos, não se devem simplesmente transplantar esses mesmos parâmetros de controle de atos administrativos discricionários, dada a natureza jurídica diversa. Por dever de obediência ao princípio da separação de Poderes, cabe ao Poder Judiciário adotar comedimento no controle do mérito do ato político. Competirá à decisão judicial, em qualquer caso, apontar qual direito foi ameaçado ou violado pelo ato político e quem são os titulares de tal direito. A simples invocação de violação aos princípios da moralidade, da razoabilidade ou da eficiência, enquanto fundamentação autônoma, deve ser rechaçada, dado o excesso de abertura semântica e a incompletude conceitual desses valores, os quais, quando muito, poderiam servir de reforço argumentativo para fundamentações constitucionais outras. Especificamente quanto à razoabilidade e à eficiência, não há sequer consenso sobre se seriam verdadeiramente princípios. No ponto, vale a lição de Humberto Ávila (2005, p. 3), para quem: 
A eficiência e a razoabilidade, embora comumente denominadas de princípios pela doutrina, são examinadas como postulados, na medida em que não impõem a realização de fins, mas, em vez disso, estruturam a realização dos fins cuja realização é imposta pelos princípios. São, por assim dizer, normas estruturantes de segundo grau.

Quanto à moralidade, a "pesquisa da imoralidade é mais exigente do que a da ilegalidade e, sem dúvida, muito mais difícil”, observa Diogo de Figueiredo Moreira Neto (1992, p. 11). Conforme preceitua a vigente ordem constitucional, um ato estatal não deve respeito apenas à juridicidade, mas também à moralidade, partindo-se da premissa de que Direito e Moral são sistemas distintos. Um dos desafios que se apresenta ao controle judicial de ato político ocorre diante de ato juridicamente válido, porém, supostamente violador de preceitos morais. O melhor exemplo recente talvez seja o "caso Cristiane Brasil", deputada federal cuja nomeação para o Ministério do Trabalho, feita pelo então presidente da República Michel Temer em 2018, foi barrada pela Justiça (Ação Popular n. 001786-77.2018.4.02.5102, da $4^{\text {a }}$ Vara Federal de Niterói-RJ, cuja liminar foi mantida pelo TRF-2, suspensa pelo STJ e restaurada pelo STF na Reclamação n. 29.508/DF), com base no princípio da moralidade administrativa, tendo em vista possuir, a nomeada, condenações em ações trabalhistas, fato que seria incompatível com o status exigido para um ministro do Trabalho.

O controle dos atos políticos juridicamente válidos, porém, supostamente imorais, não deve ficar a cargo do Poder Judiciário - cujo papel não é ser guardião da moralidade pública -, mas sim submetido ao controle popular das urnas, ao controle político do parlamento e ao controle administrativo interna corporis. Se tudo puder ser decidido com base apenas no juízo binário da moralidade versus imoralidade, a racionalidade do Direito cederá lugar à racionalidade moral, e, para o Poder Judiciário, a filosofia moral valerá mais do que a ciência jurídica.

Outro aspecto a merecer destaque diz respeito ao controle judicial exercido sobre os silêncios e as omissões quanto à produção de atos políticos pelos demais Poderes. O exemplo recente mais ilustrativo ocorreu com a decisão do ministro Marco Aurélio, do STF, quando determinou à presidência da Câmara dos Deputados, em 2016, o recebimento e a abertura de processo de impeachment, pendente de apreciação, contra o então vice-presidente da República Michel Temer (medida cautelar no Mandado 
de Segurança n. 34.087/DF). Tanto quanto um árbitro de futebol, que não deve atrasar ou adiantar o relógio da partida, não compete ao Poder Judiciário interferir no timing da política, sob pena de violação à separação de Poderes. Ressalva-se apenas uma hipótese legítima para o controle em casos tais: se a omissão na produção do ato político vulnerar diretamente o exercício de algum direito fundamental. Esse não parece ter sido o caso da liminar referida.

A solução para o impasse da sindicabilidade dos atos políticos talvez esteja na adoção das ideias de democracia deliberativa e, principalmente, das teorias do diálogo institucional. O conceito de democracia, de acordo com Habermas (1997), é articulado a partir de uma dimensão procedimental, baseada na deliberação. O processo de tomada de decisões políticas, para que ostente legitimidade democrática, precisa ocorrer a partir de uma ampla discussão pública, em que os participantes possam racionalmente debater a respeito dos diversos argumentos apresentados, para somente então decidir. Assim, o caráter deliberativo corresponde a um processo coletivo de ponderação e análise, permeado pelo discurso, que antecede a decisão.

Já as "teorias" do diálogo tentam escapar da armadilha da "última palavra" do Poder Judiciário e defendem uma atitude teórica que rompa com esse dogma. Dois são os seus denominadores comuns: a rejeição da existência de uma última palavra, ou, pelo menos, a de que as cortes constitucionais a detenha por meio da revisão judicial; e a recusa da visão juricêntrica e do monopólio judicial na interpretação da constituição, a qual é e deve ser legitimamente exercida pelos outros Poderes (MENDES, 2013).

Contra a tradição da supremacia judicial, segundo a qual as constituições são normas de ordem superior que só fazem sentido se estiverem acima da política e forem protegidas por um guardião, nasce uma corrente que recusa essa premissa a partir de variados argumentos. Propõe-se que a Constituição é um instrumento interpretável por todos os Poderes. Nesse cenário, a interpretação extrajudicial seria um fenômeno legítimo e desejável. Para os defensores da supremacia, as cortes constitucionais são soberanas na interpretação; para os defensores da democracia deliberativa, tribunais constitucionais são um intérprete a mais dentro de um complexo jogo. Haveria, portanto, vida constitucional fora das cortes, apesar de as teorias centradas na última palavra judicial ignorarem essa constatação (MENDES, 2013).

A questão normativa central não é, portanto, discutir se a interpretação extrajudicial deve ocorrer, mas saber quanta deferência os Poderes 
devem conceder-se, reciprocamente, em cada momento. A política pública é produto da interação e da negociação entre os Poderes, em cujo processo há mútuas concessões. A geometria variável desse jogo produz decisões diferentes das que seriam tomadas, isoladamente, por qualquer dessas instituições. Não se trata, pois, de um jogo de "soma zero", com vencedores de um lado e perdedores de outro, tal qual numa queda de braço. Tem-se, com mais frequência, uma relação do tipo "ganha-ganha", em que ambos os lados têm parte de seu objetivo atendido. Excetuados os momentos atípicos, o processo não é caracterizado pelo choque frontal entre pretensões opostas e inconciliáveis. Com efeito, o cotidiano político é guiado por acomodações. O Judiciário influencia o rumo das decisões dos outros dois Poderes, sem, contudo, criar impasses. Por esse prisma, sentenças não são um obstáculo insuperável, nem juízes são os heróis do povo. Tribunais aqui não são vistos como inspetores externos à política (MENDES, 2013).

A arena política preocupa-se, primariamente, com as questões de conveniência da política pública. Inobstante, considerações principiológicas também são ponderadas. Nenhum Poder está isento da responsabilidade de apresentar boas justificativas constitucionais. Essas, porém, são secundárias dentro do sopesamento que verdadeiramente conta na decisão política. A Corte, por sua vez, tem na consideração de princípio sua função primária. O processo real, portanto, estaria numa zona cinzenta entre a imposição da vontade de um só e a construção igualitária e horizontal da política pública.

Sendo a Constituição um texto aberto e flexível, interpretações são contingentes e sujeitas a mudanças constantes. Não serão aceitas como corretas para sempre. Há uma permanente dinâmica de ressignificações. Seria um processo de idas e vindas, em que o Judiciário devolve o tema para a sociedade e para os outros Poderes, e vice-versa. As partes se influenciam mutuamente e mudam suas preferências, num laborar de constitucionalismo dialógico.

E como poderia ocorrer esse diálogo institucional no âmbito do controle judicial de atos políticos? O Judiciário, ao ser provocado a revisar determinado ato ou omissão de natureza política do Poder Executivo, poderia trazer para a lide o Poder Legislativo, fiscal político natural do governo, assinalando-lhe prazo para se pronunciar sobre a impugnação. Seria uma oportunidade para o Parlamento exercer seu também legítimo papel de intérprete da Constituição. Estabelecido o contraditório com o Poder Executivo e ouvido o fiscal político natural desse Poder, haveria nítido incre- 
mento de legitimidade na atuação do Poder Judiciário, afinal mais legítima será a revisão judicial quanto mais claro estiver que o Parlamento participou da deliberação constitucional.

Em síntese, a revisão judicial tem a capacidade de subverter o status quo, mas não deve fazê-lo de maneira revolucionária. A ela não basta encontrar a decisão mais correta em matéria de princípios, pois, para além disso, vislumbrar alianças é fundamental. Não se trata, a rigor, de deixar demandas judiciais “em aberto”. Ademais, a separação de Poderes admite que a decisão final advenha da combinação da posição de mais de uma agência. É provável que assim sejam produzidas respostas mais criativas e legítimas do que num modelo conflitivo e adversarial.

A revisão judicial não serve somente para proteger os indivíduos da política quando esta sucumbe à irracionalidade, mas para desafiá-la a se superar em qualidade. Juízes podem ser catalisadores do debate constitucional, num esforço para fazer da democracia um regime que não apenas separe maiorias e minorias, promova a competição política periódica e divida as elites vencedoras e perdedoras, mas também um sistema capaz de discernir entre bons e maus argumentos. Isso é o que qualifica o debate político.

\section{Considerações finais}

Numa democracia, todo e qualquer ato estatal deve estar sujeito ao controle judicial. A responsabilidade institucional associa-se à chamada horizontal accountability e quanto mais representativos, mais responsabilizáveis serão os titulares do poder público, de modo que a responsabilidade política nada mais é do que a obrigação de prestar contas e o dever de ser fiscalizado. Posto isso, qualquer voz que se levante a defender a "insindicabilidade" dos atos de governo estará a serviço de projetos autoritários. A própria CF afasta essa hipótese, quando afirma que "a lei não excluirá da apreciação do Poder Judiciário lesão ou ameaça a direito” (art. 5, XXXV). Portanto, a discussão não é essa.

$\mathrm{Na}$ ordem do dia está o debate sobre quais os limites dessa sindicabilidade judicial. Por tudo que foi defendido neste ensaio, conclui-se não haver espaço para ativismo judicial no controle de atos políticos. Controlá-los exige do Poder Judiciário, vinculação máxima aos comandos positivados na Constituição. Visto que o ato político retira seu fundamento de legitimidade diretamente da Constituição, os requisitos formais e materiais 
que lhe conferem validade devem estar todos na própria Constituição. Com isso, não cabe ao Poder Judiciário invalidar ato político com base unicamente em parâmetros infraconstitucionais. Deve a decisão judicial, em qualquer caso, apontar qual direito foi ameaçado ou violado pelo ato político e quem são os titulares de tal direito. A simples invocação de violação aos valores constitucionais da moralidade, da razoabilidade ou da eficiência, enquanto fundamentação autônoma, é juridicamente inadequada, dado o excesso de abertura semântica e a incompletude conceitual desses institutos, os quais, quando muito, poderiam servir de reforço argumentativo para fundamentações constitucionais outras. Demais disso, o controle dos atos políticos juridicamente válidos, porém supostamente imorais, não deve ficar a cargo do Poder Judiciário - cujo papel não é ser guardião da moralidade pública -, mas sim submetido ao controle popular das urnas, ao controle político do parlamento e ao controle administrativo interna corporis. Quanto ao controle judicial exercido sobre os silêncios e omissões na produção de atos políticos pelos demais Poderes, não compete ao Poder Judiciário interferir no timing da política, sob pena de violação à separação de Poderes. Ressalva-se apenas uma hipótese legítima para o controle em casos tais: se a omissão na produção do ato político vulnerar diretamente o exercício de algum direito fundamental.

Conforme foi ponderado, a solução para o impasse da sindicabilidade dos atos políticos talvez esteja na adoção das ideias de democracia deliberativa e das teorias do diálogo institucional. O Judiciário, ao ser provocado a revisar determinado ato ou omissão de governo, poderia trazer para a lide o Poder Legislativo, fiscal político natural do governo, assinalando-lhe prazo para se pronunciar sobre a impugnação. Seria uma oportunidade para o Parlamento exercer seu também legítimo papel de intérprete da Constituição. Estabelecido, pois, o contraditório com o Poder Executivo e ouvido o fiscal político natural desse Poder, haveria nítido incremento de legitimidade na atuação do Poder Judiciário, afinal mais legítima será a revisão judicial quanto mais claro estiver que o Parlamento participou da deliberação constitucional. Em síntese, a revisão judicial tem a capacidade de subverter o status quo, mas não deve fazê-lo de maneira revolucionária, pela espada das liminares. Juízes podem ser catalisadores do debate constitucional, num esforço para fazer da democracia um regime mais cooperativo e menos adversarial. 


\section{Referências}

ARISTÓTELES. Tratado da Política. Trad. M. de Campos. Lisboa: Publicações Europa-América, 1977.

ÁVILA, Humberto. Moralidade, razoabilidade e eficiência na atividade administrativa. Revista Eletrônica de Direito do Estado, Salvador, Instituto de Direito Público da Bahia, n. 4, p. 1-25, out./dez. 2005.

CALDEIRA, Marco. Actos políticos, direitos fundamentais e constituição. Lisboa: AAFDL, 2014.

CANOTILHO, José Joaquim Gomes. Constituição dirigente e vinculação do legislador: contributo para a compreensão das normas constitucionais programáticas. 2. ed. Coimbra: Coimbra Editora, 2001.

CORREIA, José de Matos; PINTO, Ricardo Leite. A responsabilidade política. Lisboa: Universidade Lusíada, 2010.

CRETELLA JÚNIOR, José. Teoria do ato de governo. Revista de Informação Legislativa, Brasília, a. 24, n. 95, p. 73-84, jul./set. 1987.

DIAS, Eduardo Rocha; SÁ, Fabiana Costa Lima de. O ativismo judicial à luz do pensamento de Konrad Hesse sobre a força normativa da Constituição. Revista de Informação Legislativa (RIL), Brasília, v. 57, n. 225, p. 165-179, jan./mar. 2020.

ENTERRÍA, Eduardo García de. La lucha contra las inmunidades del poder. 3. ed. Madrid: Civitas, 1995.

FERNÁNDEZ-VALMAYOR, José Luis Carro. La doctrina de acto político. Revista de Administración Pública, Madrid, v. 53, p. 73-130. 1967.

GARAPON, Antoine. O guardador de promessas: justiça e democracia. Trad. Francisco Aragão. Lisboa: Instituto Piaget, 1996.

HABERMAS, Jürgen. Direito e democracia: entre facticidade e validade. Vol. I. Rio de Janeiro: Tempo Brasileiro, 1997.

HAMILTON, Alexander; MADISON, James; JAY, Jonh. O federalista. Trad. Heitor Almeida Herrera. Brasília: Universidade de Brasilia, 1984.

HESSE, Konrad. A força normativa da constituição. Trad. Gilmar Ferreira Mendes. Porto Alegre: Sergio Antonio Fabris Editor, 1991.

JUSTEN FILHO, Marçal. Curso de Direito Administrativo. 10. ed. São Paulo: Revista dos Tribunais, 2014. 
LOMBA, Pedro. Teoria da responsabilidade política. Coimbra: Coimbra Editora, 2008.

MARSHALL, Willian P. Conservatism and the Seven Signs of Judicial Activism. University of Colorado Law Review, Chapel Hill, n. 73, p. 101-140. 2002.

MEDAUAR, Odete. Ato de Governo. Revista de Direito Administrativo, Rio de Janeiro, v. 191, p. 67-85, jan. 1993.

MEDAUAR, Odete. Direito administrativo moderno. 10. ed. São Paulo: RT, 2006.

MENDES, Conrado Hübner. Constitutional courts and deliberative democracy. Oxford: Oxford University Press, 2013.

MONTESQUIEU, Barão de (Charles-Louis de Secondat). Do espírito das leis. Trad. Pedro Vieira Mota. São Paulo: Saraiva, 2008.

MOREIRA NETO, Diogo de Figueiredo. Moralidade Administrativa: do conceito à efetivação. Revista de Direito Administrativo, Rio de Janeiro, v. 190, p. 1-44, out./nov. 1992.

OLIVEIRA NETO, Francisco José Rodrigues de. A estrita legalidade como limitador democrático da atividade jurisdicional. Pensar, Fortaleza, v. 16, n. 2, p. 527-561, jul./dez. 2011.

OTERO, Paulo. Instituições políticas e constitucionais. Vol. I. Coimbra: Almedina, 2007.

PIÇARRA, Nuno. A separação dos poderes como doutrina e princípio constitucional: um contributo para o estudo das suas origens e evolução. Coimbra: Coimbra Editora, 1989.

POGREBINSCHI, Thamy. Ativismo judicial e direito: considerações sobre o debate contemporâneo. Direito, Estado e sociedade. Rio de Janeiro: PUC, 2000 .

QUEIROZ, Cristina M. Os actos políticos no Estado de Direito: o problema do controle político do poder. Coimbra: Almedina, 1990.

SOUSA, Marcelo Rebelo de. O valor jurídico do acto inconstitucional. Lisboa: Gráfica Portuguesa, 1988.

STRECK, Lenio Luiz. Hermenêutica jurídica e(m) crise: uma exploração hermenêutica da construção do direito. 5. ed. Porto Alegre: Livraria do Advogado, 2004. 
TEIXEIRA, Anderson Vichinkeski. Ativismo judicial: nos limites entre racionalidade jurídica e decisão política. Revista Direito GV, São Paulo, v. 8, p. 37-57. 2012.

TRINDADE, André Karam. Garantismo versus neoconstitucionalismo: os desafios do protagonismo judicial em terrae brasilis. In: FERRAJOLI, Luigi; STRECK, Lenio; TRINDADE, André Karam (Org.). Garantismo, hermenêutica e (neo)constitucionalismo: um debate com Luigi Ferrajoli. Porto Alegre: Livraria do Advogado, 2012. p. 95-131.

WEBER, Max. Ensaios de sociologia. Trad. Waltensir Dutra. 5. ed. Rio de Janeiro: LTC, 1982.

WOLFE, Christopher. The rise of modern judicial review: from constitutional interpretation to judge-made law. Nova York: Rowman \& Littefieleld, 1994

Luis Lima Verde Sobrinho - Doutorando e Mestre em Direito Constitucional pela Universidade de Fortaleza - UNIFOR. Professor da graduação da Faculdade de Direito do Centro Universitário UniAteneu e da especialização em Direito Público da Universidade Estácio de Sá. Formador credenciado junto à Escola Superior da Magistratura do Estado do Ceará - ESMEC e à Escola Nacional de Formação e Aperfeiçoamento de Magistrados - ENFAM. Membro associado do Conselho Nacional de Pesquisa e Pós-Graduação em Direito - CONPEDI. Membro do Grupo de Pesquisa Estado, Política e Constituição (CNPq/UNIFOR). Analista Judiciário e Consultor Jurídico da Presidência do Tribunal de Justiça do Estado do Ceará - TJCE. 